\title{
Commentary Unraveling the role of high mobility group box protein 1 in severe trauma

\author{
Edward Abraham
}

Department of Medicine, University of Alabama at Birmingham, Birmingham, AL 35294, USA

Corresponding author: Edward Abraham, eabraham@uab.edu

See related research by Cohen et al., http://ccforum.com/content/13/6/R174

Published: 12 November 2009

This article is online at http://ccforum.com/content/13/6/1004

(C) 2009 BioMed Central Ltd

Critical Care 2009, 13:1004 (doi:10.1186/cc8141)

\begin{abstract}
High mobility group box protein 1 (HMGB1) has been shown to participate in acute inflammatory reactions, including acute lung injury and sepsis. There is also evidence that circulating levels of HMGB1 are increased after severe trauma and are associated with clinically important outcome parameters, including mortality. Recent studies demonstrated that HMGB1 itself has little or no proinflammatory activity, but is able to potentiate inflammatory responses through binding to mediators, such as endotoxin or cytokines. Important questions are to determine the binding partners for HMGB1 in the setting of severe injury and whether inhibition of interactions of HMGB1 and associated molecules with the cell surface can affect outcome after trauma.
\end{abstract}

High mobility group box protein 1 (HMGB1) has long been known to participate as a nuclear cofactor in the regulation of transcriptional events. However, over the past several years, HMGB1 has been demonstrated to be secreted by cells, such as macrophages, activated by lipopolysaccharide and other mediators associated with sepsis and acute inflammatory processes. A study that now appears in Critical Care not only shows that plasma HMGB1 levels are elevated within less than an hour after severe trauma but also reports an association between HMGB1 levels and severity of injury and survival [1]. These results are consistent with those previously reported in which serum concentrations of HMGB1 were found to be increased within 1 hour of severe trauma, but did not correspond with outcome [2]. The differences in the relationship between outcome and circulating HMGB1 concentrations reported in the two studies are likely to reflect the much larger patient population enrolled by Cohen and colleagues [1], especially as multiple reports from patients with severe sepsis also have found that higher HMGB1 levels in the period immediately after hospitalization were associated with worse clinical outcome $[3,4]$.
Initial studies suggested that HMGB1 acted as a proinflammatory mediator and was capable of contributing to organ system dysfunction and mortality in animal models of sepsis $[5,6]$. However, recent experiments using highly purified HMGB1 have brought into question the ability of HMGB1 to activate cells and directly participate in acute inflammatory conditions $[7,8]$. Rather, HMGB1 appears to potentiate inflammatory responses through avidly binding to proinflammatory mediators, including lipopolysaccharide, interleukin-1, and DNA [7,9]. The lack of endogenous inflammatory activity of HMGB1 itself in cell culture experiments is consistent with the finding that high circulating levels of HMGB1 are present in patients who are clinically recovering from severe infection, such as pneumonia [10].

Although Cohen and colleagues hypothesize that the increased levels of HMGB1 found after severe trauma may contribute to organ system dysfunction and mortality in this clinical setting, these results are also consistent with the interpretation that HMGB1 is simply an innocent bystander and marker of hypoperfusion and tissue injury after trauma. In this study, plasma levels of HMGB1 were correlated with proinflammatory mediators, such as TNF- $\alpha$, alterations in coagulation, and complement activation. Each of these factors may contribute to organ dysfunction and mortality after trauma without invoking a role for HMGB1.

The ability of HMGB1 to bind proinflammatory mediators and to potentiate cellular activation associated with interaction of such mediators with their receptors raises questions about a potentially important ancillary role for HMGB1 in enhancing inflammatory responses and contributing to organ dysfunction after trauma. For example, HMGB1 is known to bind to TNF- $\alpha$, a cytokine whose levels are increased after trauma

HMGB1 = high mobility group box protein $1 ; \mathrm{TNF}=$ tumor necrosis factor. 
and which is well known to produce organ dysfunction. Association between HMGB1 and TNF- $\alpha$ is likely to potentiate the proinflammatory effects of TNF- $\alpha$ after trauma, thereby worsening organ dysfunction. Additional studies aimed at characterizing the co-factors bound to HMGB1 in the setting of severe accidental injury would be extremely useful in delineating the mechanisms through which HMGB1 may contribute to outcome in this clinical setting.

Antibodies to HMGB1 improve outcome in animal models of sepsis, clearly demonstrating a role for HMGB1 in contributing to mortality in severe infection $[6,11]$. While initial studies postulated that the benefit from blocking HMGB1 was through inhibiting direct deleterious effects of HMGB1 on organ function, it would now appear that antiHMGB1 therapies owe their efficacy to diminishing the adjuvant role of HMGB1 in potentiating inflammatory responses through enhanced presentation of bound mediators to their cellular receptors. A similar situation may occur in trauma where antibodies and other therapies capable of enhancing the clearance of HMGB1 and its bound proinflammatory co-factors or of inhibiting interactions of HMGB1 with macrophages and other cell populations that are involved in acute inflammatory responses may have a beneficial effect on clinical outcome. Appropriately designed clinical trials will be necessary to answer this question.

\section{Competing interests}

The authors declare that they have no competing interests.

\section{References}

1. Cohen MJ, Brohi K, Calfee CS, Rahn P, Chesebro BB, Christiaans SC, Carles M, Howard M, Pittet J-F: Early release of high mobility group box nuclear protein 1 after severe trauma in humans: role of injury severity and tissue hypoperfusion. Crit Care 2009, 13:R174.

2. Peltz ED, Moore EE, Eckels PC, Damle SS, Tsuruta Y, Johnson JL, Sauaia A, Silliman CC, Banerjee A, Abraham E: HMGB1 is markedly elevated within 6 hours of mechanical trauma in humans. Shock 2009, 32:17-22.

3. Hatada T, Wada H, Nobori T, Okabayashi K, Maruyama K, Abe Y, Uemoto S, Yamada S, Maruyama I: Plasma concentrations and importance of High Mobility Group Box protein in the prognosis of organ failure in patients with disseminated intravascular coagulation. Thromb Haemost 2005, 94:975-979.

4. Wang $\mathrm{H}$, Yang $\mathrm{H}$, Tracey $\mathrm{KJ}$ : Extracellular role of HMGB1 in inflammation and sepsis. J Intern Med 2004, 255:320-331.

5. Wang $\mathrm{H}$, Yang $\mathrm{H}$, Czura CJ, Sama AE, Tracey KJ: HMGB1 as a late mediator of lethal systemic inflammation. Am J Respir Crit Care Med 2001, 164:1768-1773.

6. Wang $\mathrm{H}$, Bloom $\mathrm{O}$, Zhang $\mathrm{M}$, Vishnubhakat JM, Ombrellino $\mathrm{M}$, Che J, Frazier A, Yang H, Ivanova S, Borovikova L, Manogue KR, Faist E, Abraham E, Andersson J, Andersson U, Molina PE, Abumrad NN, Sama A, Tracey KJ: HMG-1 as a late mediator of endotoxin lethality in mice. Science 1999, 285:248-251.

7. Tian J, Avalos AM, Mao SY, Chen B, Senthil K, Wu H, Parroche P, Drabic S, Golenbock D, Sirois C, Hua J, An LL, Audoly L, La Rosa G, Bierhaus A, Naworth P, Marshak-Rothstein A, Crow MK, Fitzgerald KA, Latz E, Kiener PA, Coyle AJ: Toll-like receptor 9-dependent activation by DNA-containing immune complexes is mediated by HMGB1 and RAGE. Nat Immunol 2007, 8:487-496.

8. Rouhiainen A, Tumova S, Valmu L, Kalkkinen N, Rauvala $\mathrm{H}$ : Pivotal advance: analysis of proinflammatory activity of highly purified eukaryotic recombinant HMGB1 (amphoterin). J Leukoc Biol 2007, 81:49-58.
9. Sha Y, Zmijewski J, Xu Z, Abraham E: HMGB1 develops enhanced proinflammatory activity by binding to cytokines. I Immunol 2008, 180:2531-2537.

10. Angus DC, Yang L, Kong L, Kellum JA, Delude RL, Tracey KJ, Weissfeld L: Circulating high-mobility group box 1 (HMGB1) concentrations are elevated in both uncomplicated pneumonia and pneumonia with severe sepsis. Crit Care Med 2007 35:1061-1067.

11. Yang $H$, Ochani M, Li J, Qiang $X$, Tanovic M, Harris HE, Susarla SM, Ulloa L, Wang H, DiRaimo R, Czura CJ, Wang H, Roth J, Warren HS, Fink MP, Fenton MJ, Andersson U, Tracey KJ: Reversing established sepsis with antagonists of endogenous high-mobility group box 1 . Proc Natl Acad Sci USA 2004, 101:296-301. 